\title{
PENGARUH MEDIA AUDIO VISUAL DENGAN METODE DEMONSTRASI DALAM PEMBELAJARAN TARI SIGEH PENGUTEN PADA SISWA KELAS VIII SMP NEGERI 31 PALEMBANG
}

\author{
Oleh: \\ Tri Maetasari \\ (Guru Seni Budaya SMP Negeri 1 Kebun Tebu Lampung Barat)
}

\begin{abstract}
ABSTRAK
Permasalahan dalam penelitian ini adalah apakah penggunaan metode demonstrasi denganmedia audio visual memberikan pengaruh terhadap pembelajaran tari Sigeh Penguten kepada siswa kelasVIII SMP Negeri 31 Palembang. Tujuan penelitian ini adalah untuk mengetahui pengaruh penggunaan metode demonstrasi dengan media audio visual terhadap pembelajaran tari Sigeh Penguten kepada siswa kelas VIII SMP Negeri 31 Palembang. Populasi dalam penelitian ini adalah seluruh siswa kelas VIII di SMP Negeri 31 Palembang.Sampel dalam penelitian ini adalah siswa kelas VIII.1 yan g berjumlah 31 orang siswa SMP Negeri 31Palembang. Hipotesis dalam penelitian ini adalah ada pengaruh penggunaan metode demonstrasi dengan media audio visual terhadap pembelajaran tari Sigeh Penguten kepada siswa kelas VIII SMP Negeri 31 Palembang. Metode yang digunakan adalah eksperimen. Pada pengumpulan data menggunakan tes kerja. Teknik analisis data berbentuk deskriptif kuantitatifmenghitung dengan statistik. Teknik analisis data adalah tes unjuk kerja dilakukan oleh peneliti untuk mengetahui hasil belajar siswa, kemudian hasil tes unjuk kerja akan dianalisis oleh peneliti guna mengetahui seberapa besar pengaruh penggunaan metode demonstrasi dengan media audio visual terhadap pembelajaran tari Sigeh Penguten terhadap hasil belajar siswa kelas VIII SMP Negeri 31 Palembang
\end{abstract}

Kata Kunci: Pengaruh, Demonstrasi, Audio Visual, Sigeh Penguten

\section{A. PENDAHULUAN}

Menurut Tim Penyusun (2012:263), pendidikan adalah proses pengubahan sikap dan tata laku seseorang atau kelompok orang dengan usaha mendewasakan manusia melalui upaya pengajaran dan pelatihan: proses, cara, perbuatan mendidik.

Sekolah memiliki peran yang sangat penting sebagai upaya mengembangkan proses pendidikan berlangsung, sekolah merupakan rumah kedua untuk mendapatkan pendidikan setelah pendidikan pertama didapat melalui rumah dan orang tua. Sekolah merupakan salah satu pendidikan, yang secara formal bertanggung jawab atas berlangsungnya proses pendidikan, sehingga guru dituntut untuk melaksanakan tanggung jawab tersebut yaitu dengan berusaha mengembangkan kegiatan pembelajaran agar dapat berlangsung secara optimal. Untuk itu perlu diciptakan situasi yang memberikan rangsangan belajar, mengajarkan kegiatan belajar dan mengelola kegiatan belajar secara efisien. Kegiatan 
inilah yang disebut mengajar. Peran siswa adalah berusaha secara aktif untuk mengembangkan dirinya di bawah bimbingan guru. Oleh karena itu fungsi belajar siswa sangat menentukan keberhasilan pendidikan. Ini berarti bahwa berhasil tidaknya pencapaian tujuan pendidikan bergantung pada bagaimana proses belajar yang dilakukan oleh siswa sebagai peserta didik.

Kegiatan belajar mengajar di SMP Negeri 31 Palembang dalam mata pelajaran seni budaya salah satunya diajarkan tari nusantara. Menurut Bahari, (2008:62) seni adalah suatu keterampilan yang diproleh dari pengalaman, belajar, atau pengamatanpengamatan. Pengertian lainnya, seni merupakan bagian dari pelajaran, salah satunya ilmu sastra, dan pengertian kekuatan aspek genetik (Bahari, 2008 : 9). Dalam pendidikan seni tari tidak hanya menuntut keterampilan gerak saja melainkan menggunakan emosional dan fikiran, karena dalam membawakan suatu gerak tari, diperlukan pula suatu penguasaan teknik gerak seuai dengan irama.

Dalam kurikulum 2006, pendidikan seni tari merupakan salah satu materi pelajaran yang diajarkan kepada peserta didik. Untuk itu peneliti berniat untuk meneliti peserta didik kelas VIII di SMP Negeri 31 Palembang, dengan materi ajar tari Sigeh Penguten yang berasal dari daerah Lampung.
Tarian ini merupakan tari sambut untuk para tamu agung, tarian ini merupakan tarian tradisional. Tari Sigeh Penguten merupakan tarian persembahan untuk menyambut kedatangan para raja dan tamu istimewa selain diperagakan di upacara-upacara adat serta upacara penyambutan tamu agung, tari Sigeh Penguten juga sering diperagakan di acara pernikahan adat Lampung. Berdasarkan observasi yang dilakukan oleh peneliti di SMP Negeri 31 Palembang terdapat masalah yang dihadapi yaitu siswa belum memahami secara luas tentang tari nusantara terutama tari nusantara yang berasal dari Provinsi Lampung yaitu tari Sigeh Penguten. Dalam proses belajar mengajar guru hanya memberi tugas kepada sippengetatabamancapielgatan tari dengangetahuan serta menggunakan media audio visual, tetapi guru tersebut tidak secara langsung menjelaskan detail salah satu tarian nusantara. Dari observasi tersebut peneliti mencoba mengenalkan dan menjelaskan salah satu tarian nusantara yaitu Sigeh Penguten dari Provinsi Lampung, serta penelitipun mengajak siswa untuk mengikuti gerakgerakan tarian dengan harapan siswa tidak hanya mengenal tari daerah setempat saja tetapi mereka juga dapat mengenal tari nusantara lainnya terutama dari provinsi Lampung, tidak hanya mampu menggerakan bagian-bagian gerakan tari, tetapi siswa juga mengetahui sejarah dari tari 
Sigeh Penguten ini. Pembelajaran akan dianggap tepat dengan menggunakan metode demonstrasi. Metode demonstrasi adalah metode pembelajaran dengan menggunakan strategi pengajaran dengan cara memberi pengalaman belajar melalui perbuatan melihat dan mendengarkan diikuti dengan meniru pekerjaan yang didemontrasikan. Menurut Djamarah dan Zain (2013:90), metode demonstrasi adalah cara penyajian pelajaran dengan meragakan suatu pertunjukan kepada siswa suatu proses, situasi atau benda tertentu yang sedang dipelajari, baik sebenarnya ataupun tiruan, yang sering disertai dengan penjelasan lisan.

Di samping metode pembelajaran, untuk menciptakan kondisi belajar sebaik mungkin, guru hendaknya menggunakan media yang merupakan salah satu faktor yang turut menentukan keberhasilan pembelajaran. Dalam prose belajar mengajar, kehadiran media mempunyai arti yang cukup penting, karena dalam kegiatan tersebut ketidak jelasan bahan yang disampaikan dapat dibantu dengan menghadirkan media sebagai perantara, media dapat mewakili apa yang kurang mampu guru ucapkan melalui kata-kata atau kalimat tertentu. Menurut Djamarah dan Zain (2013:121), media adalah alat bantu apa saja yang dapat dijadikan sabagai penyalur pesan guna mencapai tujuan pengajaran. Oleh karena, itu media pembelajaran sangat membantu guru untuk menyampaikan pesanpesan dari bahan pembelajaran yang akan disampaikan oleh peserta didik.

Dengan menggunakan media diharapkan pembelajaran yang terjadi dapat meningkatkan prestasi belajar siswa, seperti membaca, melihat gambar, melihat video, radio, film ataupun diagram. Beberapa media yang dapat meningkatkan minat belajar siswa yaitu berupa video, gambar, film, dan rekaman disebut dengan media audio visual, Menurut Djamarah dan Zain, (2013:124) media audio visual adalah media yang mempunyai unsur suara dan unsur gambar. Dengan menggunakan media audio visual dapat membantu daya minat belajar peserta didik.

Berdasarkan latar belakang di atas dengan masalah-masalah yang diuraikan maka peneliti tertarik untuk mengadakan penelitian dengan judul penelitian."Pengaruh Media Audio Visual dengan Metode Demonstrasi dalam Pembelajaran Tari Sigeh Penguten kepada Siswa kelas VIII SMP N 31 Palembang".

\section{B. METODE PENELITIAN}

Menurut Arikunto (2012:203), metode penelitian adalah cara yang digunakan oleh peneliti dalam mengumpulkan data penelitiannya. Menurut Sugiyono, (2012:2) metode penelitian pada dasarnya 
merupakan cara ilmiah untuk mendapatkan data dengan tujuan dan kegunaan tertentu. Dalam penelitian ini, peneliti menggunakan metode eksperimen. Menurut Arikunto (2012:9) eksperimen adalah suatu cara untuk mencari hubungan sebab akibat (hubungan kausal) antara dua faktor yang sengaja ditimbulkan oleh peneliti dengan mengeliminasi atau mengurangi atau menyisihkan faktor-faktor lain yang mengganggu. Eksperimen selalu dilakukan dengan maksud untuk melihat akibat suatu perlakuan. Metode penelitian eksperimen yang digunakan oleh peneliti dengan maksud untuk mengetahui ada atau tidaknya pengaruh dari metode demonstrasi dan media audio visual terhadap hasil belajar siswa dalam pembelajaran tari Sigeh Penguten kelas VIII SMP Negeri 31 Palembang.

Dalam penelitian ini, peneliti menggunakan Pre-Experimental Designs yaitu One-Grup Pretest-Posttest Designs. Menurut Sugiyono (2012:74), PreExperimental Designs belum merupakan eksperimen sungguh-sungguh, karena masih terdapat variabel luar yang ikut berpengaruh terhadap terbentuknya variabel dependen. One- Grup PretestPosttest Designs merupakan desain yang terdapat pretest sebelum diberi perlakuan. Dengan demikian perlakuan dapat diketahui lebih akurat, karena dapat membandingkan dengan keadaan sebelum diberi perlakuan.

\section{PEMBAHASAN DAN HASIL PENELITIAN}

Penelitian ini dilaksanakan di SMP Negeri 31 Palembang, yang terletak di Jl. Demak, Kel. Tuan Kentang, Kec. Seberang Ulu I, Palembang. Penelitian ini dilakukan pada siswa kelas VIII semester ganjil SMP N 31 Palembang tahun ajaran 2016/2017. Penelitian ini dilaksanakan selama dua minggu dengan 4 kali pertemuan.

Pertemuan pertama, peneliti membahas teori tari Sigeh Penguten, dan mempraktikkan tari Sigeh Penguten dengan gerak-gerak dasar. Pertemuan kedua, penelti menerapkan metode demonstrasi dengan mempraktikkan didepan kelas, gerak tari Sigeh Penguten, dan siswa-siswi mengikutinya. Pertemuan ketiga, peneliti menunjukan media pembelajaran audio visual dalam bentuk video Compack Disk dan memberi praktik secara langsung didepan kelas. Pertemuan keempat, peneliti memberi penilaian terhadap siswa-siswi dengan penilaiannya meliputi: wiraga, wirasa, dan wirama. Adapun tujuan penelitian ini adalah untuk mengetahui adakah pengaruh metode demonstrasi dengan media audio visual terhadap hasil pembelajaran siswa-siswi pada mata pelajaran seni budaya, materi tari Sigeh Penguten, dengan sampel penelitian yang 
terdiri dari satu kelas yaitu kelas VIII sebagai kelas eksperimen, yang berjumlah 31, yang terdiri dari 9 siswa laki-laki dan 22 siswi perempuan, tanpa kelas pembanding (kelas kontrol).

Sebelum memulai penelitian di kelas, peneliti menyiapkan Rencana Pelaksanaan Pembelajaran (RPP) untuk kelas eksperimen. Setelah pokok materi tari Sigeh Penguten tuntas dibahas, diadakan tes pada kelas eksperimen. Tes yang diberikan berbentuk praktik.

\begin{tabular}{|c|c|c|c|c|}
\hline \multirow[b]{2}{*}{$\begin{array}{c}\text { No Urut } \\
\text { Siswa }\end{array}$} & \multicolumn{3}{|c|}{ Aspek Penilaian } & \multirow[b]{2}{*}{$\begin{array}{c}\text { Jumlah } \\
\text { skor }\end{array}$} \\
\hline & $\begin{array}{l}\text { Wiraga } \\
(10-30)\end{array}$ & $\begin{array}{r}\text { Wirama } \\
(10-30)\end{array}$ & $\begin{array}{l}\text { Wirasa } \\
(10-40)\end{array}$ & \\
\hline 1 & 15 & 20 & 25 & 60 \\
\hline 2 & 15 & 15 & 20 & 50 \\
\hline 3 & 20 & 20 & 20 & 60 \\
\hline 4 & 25 & 15 & 25 & 65 \\
\hline 5 & 20 & 15 & 25 & 60 \\
\hline 6 & 15 & 20 & 15 & 50 \\
\hline 7 & 20 & 15 & 15 & 50 \\
\hline 8 & 15 & 15 & 25 & 55 \\
\hline 9 & 20 & 20 & 20 & 60 \\
\hline 10 & 30 & 15 & 20 & 65 \\
\hline 11 & 20 & 20 & 30 & 70 \\
\hline 12 & 20 & 15 & 15 & 50 \\
\hline 13 & 15 & 20 & 20 & 55 \\
\hline 14 & 15 & 15 & 20 & 50 \\
\hline 15 & 20 & 15 & 20 & 55 \\
\hline 16 & 15 & 15 & 30 & 60 \\
\hline 17 & 25 & 10 & 35 & 70 \\
\hline 18 & 16 & 17 & 27 & 60 \\
\hline 19 & 15 & 15 & 32 & 62 \\
\hline 20 & 20 & 20 & 21 & 61 \\
\hline 21 & 20 & 10 & 20 & 50 \\
\hline
\end{tabular}




\begin{tabular}{|l|l|l|l|l|}
\hline 22 & 15 & 15 & 25 & 55 \\
\hline 23 & 21 & 17 & 25 & 63 \\
\hline 24 & 15 & 20 & 30 & 65 \\
\hline 25 & 30 & 15 & 30 & 75 \\
\hline 26 & 20 & 20 & 20 & 60 \\
\hline 27 & 15 & 15 & 30 & 60 \\
\hline 28 & 15 & 25 & 25 & 65 \\
\hline 29 & 20 & 11 & 35 & 66 \\
\hline 30 & 30 & 20 & 25 & 70 \\
\hline 31 & 30 & 15 & 30 & 75 \\
\hline
\end{tabular}

HASIL NILAI POSTTEST PEMBELAJARAN TARI SIGEH PENGUTEN
\begin{tabular}{|c|c|c|c|c|}
\hline \multirow{2}{*}{$\begin{array}{c}\text { No Urut } \\
\text { Siswa }\end{array}$} & \multicolumn{3}{|c|}{ Aspek Penilaian } \\
\cline { 2 - 5 } & Wiraga & Wirama & Wirasa & Jumlah Skor \\
\hline 1 & 25 & 25 & 30 & 80 \\
\hline 2 & 30 & 25 & 26 & 81 \\
\hline 3 & 30 & 25 & 26 & 81 \\
\hline 4 & 30 & 27 & 30 & 82 \\
\hline 5 & 25 & 25 & 35 & 85 \\
\hline 6 & 30 & 25 & 35 & 90 \\
\hline 7 & 30 & 25 & 35 & 90 \\
\hline 8 & 30 & 30 & 35 & 95 \\
\hline 9 & 25 & 25 & 30 & 80 \\
\hline 10 & 25 & 25 & 30 & 80 \\
\hline 11 & 25 & 25 & 40 & 90 \\
\hline 12 & 30 & 15 & 30 & 75 \\
\hline 13 & 30 & 25 & 39 & 94 \\
\hline 14 & 25 & 25 & 32 & 82 \\
\hline 15 & 20 & 25 & 35 & 80 \\
\hline 16 & 30 & 15 & 30 & 75 \\
\hline 17 & 25 & 30 & 38 & 93 \\
\hline 18 & 27 & 25 & 30 & 82 \\
\hline 19 & 25 & 25 & 33 & 83 \\
\hline
\end{tabular}




\begin{tabular}{|l|l|l|l|l|}
\hline 20 & 25 & 25 & 35 & 85 \\
\hline 21 & 25 & 24 & 35 & 85 \\
\hline 22 & 30 & 30 & 30 & 90 \\
\hline 23 & 28 & 25 & 30 & 83 \\
\hline 24 & 25 & 25 & 40 & 90 \\
\hline 25 & 20 & 27 & 35 & 82 \\
\hline 26 & 26 & 25 & 30 & 81 \\
\hline 27 & 30 & 27 & 35 & 92 \\
\hline 28 & 25 & 25 & 30 & 80 \\
\hline 29 & 30 & 25 & 35 & 90 \\
\hline 30 & 25 & 20 & 35 & 80 \\
\hline 31 & 30 & 30 & 35 & 95 \\
\hline
\end{tabular}

Setelah diketahui besarnya nilai 1,669 (dikonsultasikan dengan tabel distribusi t) maka dapat disimpulkan hipotesis bahwa ada pengaruh penggunaan media audio visual dengan metode demonstrasi dalam pembelajaran sesuai dengan kriteria penguji Hipotesis bahwa Ha diterima jika $\mathrm{t}$ hitung $>\mathrm{t}$ tabel, berarti Ho ditolak. Maka dapat disimpulkan ada pengaruh signifikan penggunaan metode demonstrasi dengan media audio visual terhadap pembelajaran tari Sigeh Penguten pada siswa kelas VIII.

\section{PEMBAHASAN DAN HASIL PENELITIAN}

Sampel dalam penelitian ini adalah siswa kelas VIII 1 di SMP N 31 Palembang, penelitian bertujuan untuk mencari pengaruh penggunaan metode demonstrasi dengan media audio visual terhadap hasil belajar tari Sigeh Penguten. Peneliti menggunakan evaluasi yang berupa tes praktik sebelum perlakuan (pretest) dan tes praktik sesudah perlakuan (posttest), adapun langkah-langkah sebagai berikut.

Pada awal pertemuan peneliti membahas teori tari Sigeh Penguten, dan mempraktikkan tari Sigeh Penguten dengan gerak gerak dasar, kemudian peneliti memberi penilaian kepada siswa-siswi melalui tes praktik dengan gerak gerak dasar yang diberikan, pertemuan selanjutnya peneliti menerapkan metode demonstrasi dengan mempraktikkan gerak tari Sigeh Penguten dan siswa-siswi mengikutinya. Pada pertemuan ketiga peneliti menunjukan media pembelajaran audio visual dalam bentuk Video Compact Disk dan memberikan praktik secara langsung didepan kelas. Pertemuan terakhir peneliti memberikan penilaian terhadap siswa-siswi dengan memberi tes praktik penilaiannya meliputi, wiraga, wirama, dan wirasa. Setelah pretest dan posttest dilakukan 
selanjutnya hasil evaluasi dianalisis dengan menggunakan uji statistik yang berupa uji normalitas data dan uji hipotesis, untuk mengetahui adanya pengaruh metode demonstrasi dengan media audio visual.

Dari hasil perhitungan yang didapat untuk kelas eksperimen, saat diteliti uji normalitas data (Posttest) yang diperoleh adalah $\mathrm{Km}=$ 0,67 sedangkan untuk kelas eksperimen sebelum diteliti ( pretest) diperoleh $\mathrm{Km}=$ 0,11 , harga-harga tersebut terletak antara (-1) dan (1), sehingga dapat dikatakan data Pretest dan Posttest kelas eksperimen terdistribusi normal.

\section{SIMPULAN}

Berdasarkan hasil penelitian data pembahasan dapat disimpulkan bahwa metode pembelajaran demonstrasi dengan menggunakan media audio visual yang diterapkan pada siswa kelas VIII 1 cukup membantu dalam memahami pelajaran seni budaya khususnya pada seni tari sehingga hasil belajar siswa mengalami peningkatan. Evaluasi pembelajaran yang diterapkan di SMP N 31 Palembang berdasarkan kompetensi dasar yaitu memeragakan tari tunggal nusantara sudah tercapai.

Pada hasil penelitian rata rata kelas yang belum menggunakan metode demonstrasi dengan media audio visual (pretest) siswa mendapat nilai rata-rata 5070 dan nilai rata-rata kelas yang menggunakan metode demonstrasi dengan media audio visual (posttest) siswa mendapat nilai rata-rata 75-95, dengan ketuntasan 80 yang diterapkan dari sekolah telah dicapai dengan baik.

\section{DAFTAR PUSTAKA}

Arikunto, Suharsimi. 2010 Prosedur Penelitian suatu Pendekatan Praktik. Jakarta: Rineka Cipta 2012 Prosedur Penelitian Suatu Pendekatan Praktik. Jakarta: Rineka Cipta

Bahari, Nooryan. 2008. Kritik Seni Wacana, Apresiasi dan Kreasi. Yogyakarta: Pustaka Pelajar

Djamarah, Syaiful Bahri dan Zain, Aswan, 2013. Strategi Belajar Mengajar. Jakarta: Rineka Cipta

Sugiyono, 2012. Metode Penelitian Pendidikan Pendekatan Kuantitatif, Kualitatif, dan R dan . Bandung: Alfabeta.

Tim Penyusun. 2012. Kamus Besar Bahasa Indonesia Edisi Baru. Jakarta: PT. Mediapustaka Phoenik. 